\title{
SERIAL KILLERS IN THE ANTIPODES: THE CASE OF CARLO LUCARELLI AND PAUL CLEAVE
}

\author{
BARBARA PEZZOTTI \\ (Victoria University of Wellington)
}

\begin{abstract}
Sommario
La relazione tra il detective e la città nel giallo contemporaneo è stata ampiamente analizzata. Sono scarsi invece studi critici sul rapporto fra il serial killer e lo spazio urbano. Nel confrontare Almost Blue (1997) e Un giorno dopo l'altro (2000) dello scrittore italiano Carlo Lucarelli e The Cleaner (2006) e Cemetery Lake (2008) dell'autore neozelandese Paul Cleave, questo articolo mira a dimostrare che nella crime fiction contemporanea la figura dell'assassino seriale arriva a spodestare l'investigatore della sua tradizionale funzione epistemologica, conferendo un nuovo senso allo spazio urbano, configurandosi così come un nuovo, postmoderno flâneur.
\end{abstract}

Several studies analyse the prominence of setting in contemporary crime fiction with a focus on the relation between the detective and the urban environment ${ }^{1}$. By contrast the serial killer's view on the place he moves in has been neglected and no studies have been published on Italian crime fiction from this perspective. In this article I aim to fill this gap, arguing that the serial killer may assume an important role in making sense of the urban environment, undermining the traditional function of the police detective or the private eye. In order to prove this point, I compare the works of two

1 After the pioneering work of Walter Benjamin (1938), see especially Geherin (2008), Most (2006), Hausladen (2000), Howell (1998), Prendergast (1992), and Roth (1995). 
crime fiction writers, the Italian Carlo Lucarelli (b 1960) ${ }^{2}$ and the New Zealander Paul Cleave (b 1978) ${ }^{3}$.

Working in the Antipodes, these two writers share some important features. Firstly, both introduced the character of the serial killer ${ }^{4}$ into local crime fiction, and both describe their serial killers in their everyday lives showing them, in Eichmann Arendt's words, as "terribly and terrifyingly normal" (cited in Halbertstam, 1991:37-53); secondly, both are notable for their cinematic style and, in particular, for intertwining various narrative strands in their stories, shifting from the first-person point of view to the third-person narration; thirdly, both juxtapose the official image of the city where they set their stories with a darker reality of crime and corruption; in both writers the perception of the city is delivered through different characters, such as the police detective or the private eye, various people involved in the investigation and, most interestingly, the serial killer; finally, the cities they depict in their novels, namely Bologna and Christchurch, are similar, insofar as they are both university cities pervaded by a youth and punk culture. In particular, Bologna, called $l a$

2 Lucarelli was born in Parma. A former crime reporter, he is now a TV celebrity and hosts a show about unsolved crimes and mysteries in Italy. He is the author of historical detective novels set in the 1930s and 1940 and has written two series set in contemporary Bologna. The second series, analysed in this article, includes Lupo Mannaro (1994), Almost Blue (1997) and Un giorno dopo l'altro (2000).

3

Cleave was born in Christchurch. He worked for seven years as a pawnbroker, before turning his full attention to being a writer. His first published novel, The Cleaner, was released in 2006 and became an international best-seller. The Killing Hour (2007), Cemetery Lake (2008) and Blood Men (2010) followed.

4

The term 'serial killer' was first coined by F.B.I. special agent Robert Ressler, whose accounts of tracking serial killers were very successful with U.S. readers. See Mark Seltzer (1993).

In Italy the figure of the serial killer has subsequently and successfully been used by Giorgio Faletti in his internationally acclaimed crime stories. Moreover, in the 2000s a movement called Roma noir was born, gathering various writers, such as Marco Minincangeli, Antonio Tentori, Alda Teodorani, and Ivo Scanner. In their stories these writers provide the criminal's point of view. See Elisabetta Mondello (2005). Although New Zealand writers have cultivated crime fiction (internationally the most successful of them is Ngaio Marsh [1895-1982]), it is not until the Cleave's series that there is a change of perspective from the police detective's or the private eye's point of view to the serial killer's perspective. See Joan Stevens (1966). 
dotta, the erudite, as it hosts the most ancient university in the western world (it dates back to 1088), is a prestigious university centre, has long been considered a model of good and efficient local administration, and one of the best cities to live in. This image was first spoiled in the 1970s with the death of the student Francello Lorusso who was killed by the police during an anti-Government demonstration; it was subsequently shaken by the strage di Bologna in 1980, a series of still unsolved murders at the University of Bologna between 1982 and 1983, and by the notorious case of the Uno Bianca gang between 1987 and 1994. For its part, Christchurch, which hosts the prestigious University of Canterbury, is considered the Garden City of New Zealand, and often appears in various international lists as one of the friendliest cities in the world. The image of Christchurch as a peaceful place was also shaken by crime news stories, such as the notorious Parker-Hulme case, that is, the murder of a woman committed by her own daughter and a girl-friend in $1954^{6}$.

Taking all these contact points, it is interesting to compare these two authors and see how they represent Bologna and Christchurch and the use they make of the figure of the serial killer in their stories. To illustrate this issue I will compare Almost Blue (1997) and Un giorno dopo l'altro (2000) by Lucarelli and The Cleaner (2006) and Cemetery Lake (2008) by Paul Cleave.

Almost Blue, which takes its title from a song by jazz musician Chet Baker, is about the hunt for the Iguana, a serial killer who assumes the features and identities of his victims, that is, all Bologna University students. Inspector Grazia Negro, one of the few female police detectives in Italian crime fiction, manages to arrest the serial killer with the help of a blind man, Simone, who overheard the Iguana's voice and is the only person able to recognise him. In Un giorno dopo l'altro Inspector Negro is in search of another serial killer

6 This case inspired Peter Jackson in making the award winning movie Heavenly Creatures (1994). In 2009 five bodies found in six weeks made the front pages of national newspapers and the city was re-christened the murder capital of New Zealand. See http://www.stuff. co.nz/sunday-star-times/news/2882838/Five-bodies-in-six-weeks-haunt-Garden-City (retrieved on 22 February 2010). See also "What lies beneath" (2010). 
called the Pit Bull. In this case she is also helped by a witness, Alessandro, a young man working for an Internet provider who by chance intercepted an awkward email conversation between Pit Bull and his boss. Both stories are told from three different points of view. In Almost Blue, the narrative intertwines three strands, using first person narrative in the case of Simone and the Iguana, and third person in the case of Inspector Negro. The same organisation of shifting perspectives is used in Un giorno dopo l'altro, where the narrative voice is also shared by three characters, Alessandro, Vittorio, aka the Pit Bull, and Inspector Negro. The Cleaner is the story of Joe, a serial killer, who by day works as a janitor in a Christchurch police station, and tortures and kills young women by night. The main narrative focuses on the serial killer, while some chapters provide the point of view of a young woman, narrated in the third person: it is thanks to Sally, Joe's colleague, that the police are finally able to realise he is the serial killer and arrest him. Finally, Cemetery Lake features Theodore Tate, an ex-police detective, who investigates some cold cases that turn out to be murders committed by a serial killer in Christchurch. In this case the narrative expresses Tate's perspective through the stream of consciousness technique.

\section{A tale of two cities}

Lucarelli chose to set most of his stories in Bologna as this city was for him the quintessence of mystery in Italy with its image of quiet and peacefulness hiding a heart of darkness (Lucarelli, 2007:56). In other words, he was intrigued by the juxtaposition of the official image of the city with the reality of crime and chaos, first described by Loriano Macchiavelli in the sergente Sarti series ${ }^{7}$ and ultimately exposed to the public through the Uno Bianca case. Cleave seems to have done exactly the same. In an interview, he explained that "Christchurch is a great setting for crime - it has two sides to it,

7 According to Michele Righini (2005), Macchiavelli contributed to creating the topos of 'Bologna nera', a new way at looking at the city that still survives in Italian public opinion. 
there's the picture perfect setting you see on postcards everywhere, but there's also a dark, Gotham City feel here which has, sadly, turned this city into the murder capital of New Zealand" (Crime Time, 2009).

In both writers' books, streets and places are cited, but Lucarelli and Cleave often manage to recreate the "culture or mindset" (Geherin, 2008:179) of the city without using detailed geography. They make clear from the very start that the setting of their stories is respectively Bologna and the Via Emilia, and Christchurch. However, they seldom mention architectural landmarks or touristic spots; rather, they succeeded in giving the flavour of the city through the description of specific typologies of its inhabitants. They both employ the figure of displacement, identified by Michel de Certeau (1984) as analogous to the linguistic figures of synecdoche, using a part for the whole, to make sense of the city through selected elements to produce what de Certeau would call "spatial stories" (108).

The reader can find the representation of the typical university student as a common feature of the city both in Almost Blue and in Cemetery Lake. In the former book, this is the case of Sara and Rita, representatives of punk and squat culture in Bologna:

Sara: ventitre anni, capelli corti e rosa, un orecchio traforato da una fila di anellini sottilissimi, le braccia ritirate dentro le maniche della camicia scozzese a quadretti enormi, le dita appena visibili, agganciate al bordo dei polsini. Nervosissima: avanti e indietro per l'appartamento che sembrava in tutto e per tutto quello di una normalissima casa popolare.

No: con Rita non ci abitava da un pezzo. Soldi: finché faceva Lettere moderne suo padre le mandava un vaglia da Napoli, poi aveva mollato e allora lui col cazzo. Quattro mesi fa: ciao Rita, ho trovato un posto in una casa occupata in via del Fratello, così non spendo niente, poi quando il Comune aveva fatto sgomberare si era trasferita con gli altri in via del Lazzaretto. Però prima le aveva trovato un'altra compagna per dividere l'appartamento. (Almost Blue, 1997:100-101) 
Then, at Teatro Alternativo, Inspector Negro, searching for the Iguana, mingles with university students who wear typical students' outfits, such as Eskimos and Palestinian kefiahs:

C'erano tre persone con le cuffie davanti a Simone. Uno era un ragazzo basso e grassoccio, con il ricevitore della traduzione simultanea in mano e gli auricolari di gommapiuma appiccicati alla pelle, stretti a metà collo come se volessero strangolarlo. L'altro era un ragazzo alto, con un eskimo grigio e un ciuffo che gli scendeva sulla fronte, schiacciato su un occhio da un passamontagna Aveva una kefiah rossa attorno al collo, sollevata quasi fino al mento e il passamontagna gli copriva le orecchie ma c'era un filo, un filo bianco che gli scendeva su una spalla, visibile lungo il soprabito fin dentro una tasca. Il terzo era un ragazzo dalla testa rasata. Anche lui aveva le cuffie come gli altri e quando si fermò un momento per accendersi una sigaretta Grazia gli vide brillare sul volto tre anellini, due agli angoli degli occhi e uno sul naso. (Almost Blue, 1997:134)

In Cemetery Lake there is a similar description of a student, which is the flatmate of another student, David:

A young guy with studs in his ear and lips and nose opens the door. He must have real fun going through the security foreplay before boarding a plane. He's squinting because the cloudy glare is too bright for him. His T-shirt reads The truth is down there with an arrow pointed to his crotch. All of a sudden, the last thing I want to know is the truth.

'David Harding?'

'No, dude, he's not here.'

'Where is he?'

The guy shrugs. 'Studying, I think. Or sleeping.'

'Sleeping?' 
'Yeah, man, you know, that thing you do in the morning after being out all night.'

'I thought people slept in the night.'

'What planet are you from?' (Cemetery Lake, 2006:102)

This dialogue between the student and the private eye conveys "a particular segment of society, a particular and identifiable perspective" (Hausladen, 2000:25). Living in a damp and crumbling flat and wearing a silly T-shirt, David's flatmate is a typical inhabitant of the New Zealand university world, just as Sara, with her earrings and pink hair is a typical Bologna university student. The reader finds another typology of Christchurch inhabitants in The Cleaner where a passenger on a bus is described as the standard embodiment of punk culture:

I sit next to some young punk. I would never dream of making conversation with him since I doubt he could talk about the weather without threatening to assault somebody. He's dressed entirely in black, with a black studded collar around his neck. He has red hair, spikes on his nose, and tap washers stretched into his earlobes. Another regular citizen of this fine city. (Cemetery Lake, 2006:102).

Both writers present the university world, with its students and 'alternative' lifestyle, its drugs and booze culture, and the punk world, with its distinctive clothes and attitudes, which are symbolic of a city characterised by ambiguous spaces, underground cultures, and new forms of criminality. According to Lucia Rinaldi (2009:123) Lucarelli's Bologna is identifiable as a postmodern metropolis with a fragmented and elusive identity, as theorised by Edward W. Soja (2000). This description could also be applied to Cleave's Christchurch.

As mentioned, the books analysed present different points of view. As Luca Somigli (2010) explains in the case of Lucarelli's works, the 
shifts in narrative perspective provide the narrative rhythm and owe much to cinematic techniques, often echoing a literary version of parallel montage. These different perspectives also contribute to creating a mysterious image of the city. In Almost Blue, Un giorno dopo l'altro and The Cleaner, the police perform a scientific investigation, but the serial killer is finally arrested with the help of outsiders, namely Simone, Alessandro and Sally. These characters also help to create a sense of a place. For example, in Almost Blue, the mysterious nature of Bologna is underlined by the perception of Simone, a blind man who spends his nights listening to casual conversations on a scanner and whose idea of the city is more temporal than physical. Speaking in the first person, he 'describes' his Bologna: "Io, Bologna, non l'ho mai vista. Ma la conosco bene, anche se probabilmente è una città tutta mia. È una città grande: almeno tre ore" (Almost Blue 1997:9) Another image of Bologna is presented in the following passage where in Un giorno dopo l'altro, Alessandro runs from Pit Bull who wants to kill him:

Grazie a Dio a Bologna ci sono i portici. Cado sulla tettoia di uno di questi e rotolo sui coppi senza riuscire a fermarmi. [...]. Non sto lontano, sto in una traversa di via Zamboni, alla fine di un semicerchio che attraversa piazza Maggiore e passa davanti alla Feltrinelli. Tutti luoghi pieni di gente, anche a quest'ora. Donne che escono dai negozi. Studenti. Tassisti che aspettano in piazza Maggiore. Studenti. Extracomunitari che vendono la roba per terra sotto i portici di via Ugo Bassi. Studenti. Studenti. Studenti. Non mi era mai sembrata così affollata come adesso, Bologna. C'è un sacco di gente che fa gruppo per attraversare la strada sotto le due torri, attenta a non farsi arrotare dagli autobus. [...] Attraverso via Ravegnana, passando davanti alla Feltrinelli. Per un momento penso di infilarmi lì, passare la rotellina all'ingresso ed entrare, ma tiro dritto. Se entro, accorcio le distanze, lui mi raggiunge e mi uccide. Vado avanti, allora, giro attorno a un fascio di biciclette ammassate 
contro una colonna e scendo per via Zamboni. (Un

giorno dopo l'altro, 2000:140-145)

Through Alessandro's eyes, the reader sees the image of an official Bologna, with its students and bicycles parked under the portici in contrast with his own stressful experience. By contrast, the dichotomy between the official image of the city and its dark heart is delivered via the figure of the serial killer. As we will see later, a peaceful Christchurch is similarly portrayed through Sally's eyes in The Cleaner.

\section{The serial killer as the new flâneur}

Pit Bull in Bologna and the Carver in Christchurch are identified from the beginning of the story and are described in their everyday lives. Pit Bull is a travelling salesman and has a girlfriend; as already mentioned, Joe aka the Christchurch Carver, pretends to have an intellectual disability and works as a cleaner in a police station. Everybody finds Joe a lovely and harmless person, and Sally tries to establish a friendship with him ${ }^{8}$. Both Pit Bull and the Christchurch Carver have a troubled relationship with their mothers, following a general trend in crime fiction that sees these characters as the product of dreadful childhoods (Peach 2006:159). In both cases, they cannot explain the reasons for their crimes, but they cannot see the reason not to do it either. They pursue their own impulses and desires, ignoring the consequences of their actions. Their behaviour becomes a metaphor and a travesty of the self-interest, and desire for power and control that characterises contemporary society. In Peach's words, their consciousness is located "at the heart of the self-referentiality of postmodernity" (168).

\footnotetext{
This is not the case with the Iguana and the serial killer in Cemetery Lake. The Iguana, who is obsessed with "I rintocchi di quelle maledette campane dell'Inferno che suonano sempre e suonano per me" (Almost Blue, 1997:17), is evocative of the "semi-theological" serial killer of the nineteenth century (Peach, 2006:150) and does not engage with the city where he commits his crimes. The serial killer of Cemetery Lake also is a mysterious figured unveiled only at the end of the story.
} 
The serial killer does not only mirror the excesses of western societies. As Gill Plain argues, in spite of being the lynchpin of the formula, providing certainty and stability at the centre of the narrative, "the detective's centrality has been eroded" (Plain, 2001:3) over the course of the centuries. She explains that variants to the original formula, evolving from the classical detective fiction to the hard boiled tradition to the metaphysical or anti-detective fiction, have compromised the function of the detective in the story. Plain's claim is that the presence of the crime is what now gives coherence to the genre. It can be argued that it is the presence of the criminal, and the serial killer in particular, that often guarantees an insight into the postmodern urban environment.

In addition to the cohesive element of the genre, these authors engage with the representation of an urban maze. The dichotomy between official and dark city is represented both in Lucarelli's and Cleave's works. In Almost Blue, the description of the official Bologna intertwines with a portrait of an underground and mysterious city, a 'labyrinth':

Ci sono strade, nel centro di Bologna, che hanno un' anima nascosta e puoi vederla solo se qualcuno te la mostra. C'è una strada nel centro di Bologna che ha un buco sotto un portico, una finestrella quadrata che sembra scavata nel muro di una casa, coperta da uno sportello di legno incassato in una cornice di ferro. È il centro di Bologna, il centro di una città di terra, ma basta dare un colpo allo sportellino di legno, che questo si apre e mostra un fiume, un corso d'acqua con case a picco, rosicchiate dall'umidità, e barche, attraccate ai moli. Poco lontano, appena voltato l'angolo, lo si può anche sentire respirare, il fiume, quasi ruggire strangolato da una chiusa, dove un attimo prima, appena qualche passo indietro, si sentiva soltanto il rumore del traffico di via Indipendenza. (Almost Blue, 1997:162-163) 
Bologna's labyrinthine structure is both literal and figurative: it is a complicated city, very hard to define and penetrate, a contradictory place where a left-wing administration and billionaire companies cohabit, four different Mafia organizations launder money from drugtrafficking, food culture coexists with Satanism, as policeman Matera explains to Inspector Negro who is new to the city:

Questa città, le aveva detto Matera, non è come le altre città. Perché non è soltanto grande, è anche complicata. $\mathrm{E}$ contradditoria. Se la guardi così, camminandoci dentro, Bologna sembra tutta portici e piazze ma se ci vai sopra con un elicottero è verde come una foresta per i cortili interni delle case, che da fuori non si vedono. E se ci vai sotto con una barca è piena d'acqua e di canali che sembra Venezia. Freddo polare d'inverno e caldo tropicale d'estate. Comune rosso e cooperative miliardarie. Quattro mafie diverse che invece di spararsi addosso riciclano i soldi della droga di tutta l'Italia. Tortellini e satanisti. Questa città non è quello che sembra, ispettore, questa città ha sempre una metà nascosta. (Almost Blue, 1997:102)

As one can see from this passage, Bologna is a city with multiple facets that is ideally (and terrifyingly) mirrored in the Iguana, the serial killer who assumes multiple identities. Moreover, the Iguana, who can easily move in the university world, and his murders highlight a world that replicates Bologna and the clandestine city hidden within:

L'Università? Quella è una città parallela, di cui si sa ancora meno. Studenti che vanno e che vengono da tutta Italia, che lasciano i corsi e poi li riprendono, che dormono da amici e parenti, che subaffittano, sempre in nero e senza ricevute e documenti. Ma lei lo sa che negli anni Settanta stavano tutti qui i terroristi, tutti nascosti a Bologna e lo sa perché? Perché in qualunque città un ragazzo strano, con un accento strano, che entra e esce di 
casa a tutte le ore del giorno e della notte e non si sa chi è, cosa fa e di che vive e a volte sparisce e poi torna, in qualunque altra città sarebbe stato notato da qualcuno, ma a Bologna no. A Bologna questo è l'identikit dello studente medio. Lei dice l'Università, ispettore? L'Università è una città clandestina. (Almost Blue, 1997:103-104)

In other words, the university world is a dark city that hides in the bowels of the official Bologna. Likewise the image of Christchurch conveyed by Cleave's novels echoes Bologna's ambiguity:

Christchurch. City of Angels this isn't. New Zealand is known for its tranquillity, its sheep and its hobbits. Christchurch is known for its gardens and violence. Throw a bag of glue in the air and a hundred beneficiaries will knock each other over in an effort to sniff from it. There isn't a lot to see. Lots of buildings, but they are all grey and spaced out. Lots of roads. They're all grey, too - like the sky most of the year.

The place is a jungle of concrete like any other cities, but the concrete has the occasional space for greenery: trees, shrubs, flowers. You can't take twenty paces without passing something out of nature. Large chunks of the city, such as the Botanic Gardens, are dedicated to showing the rest of the world how clever we are at turning seeds into plants. In these gardens are thousands of flowers and hundred of trees, but you can't go there at night without getting stabbed or shot and having your body helping them to grow. [...] Christchurch is voted one of the friendliest places in the world. By who, I have no idea. Certainly not anybody I've ever met. But despite all of this, Christchurch is my home. (The Cleaner, 2006:35-36)

In this extract, the serial killer describes Christchurch as a city of gardens and a 'jungle' at the same time and the image of peaceful 
greenery is juxtaposed with pictures of violence and death. Joe Middleton, aka the Christchurch Carver, thus seems to be able to read through the complexity of the city. With his double identity, a humble and intellectually disabled cleaner at the local police station during the day, and an astute serial killer in the night, Joe not only evokes Christchurch's own double identity, but he is also the only person really able to detect it. In The Cleaner, the dialectic between official images and heart of darkness is furthermore emphasised by the presence of yet another point of view. Joe's first person narration alternates in fact with a third-person perspective: Sally, a naive caretaker and colleague of Joe's, who offers an opposite take on Christchurch:

Christchurch is beautiful, she thinks, and she especially loves walking alongside the Avon River with its dark waters and lush green banks - a strip of nature running through the city. [...] It really is a beautiful city, she thinks. Voted friendliest in the world. It's obvious why. So many good people. Caring people. Many of the hundred-year-plus buildings have been well maintained, tying the city to its roots, and many of the renovations are done to look just as old as the building, an expensive exercise but one that keeps the city's tradition. So many flowerbeds, so many trees, a river flowing through its centre: is there anywhere else she would want to live?

(The Cleaner, 2006:68-70)

This double view on the city through the perception of two opposite characters evokes Pike's word-city as an "unstable refraction of an individual consciousness" (71), and highlights the fragmented nature of Christchurch.

In Cemetery Lake, the story takes place in the same period as The Cleaner, but refers to a different investigation, the former cop and private eye Theodore Tate senses that Christchurch is changing and describes the city as "broken" as the result of the Christchurch Carver's murders: 
Christchurch is broken. What didn't make sense five years ago makes sense now, not because our perspectives have changed but simply because that's the way it is. All of us are locked into a belief of how this city should be, but it's slipping away from us, nobody able to keep a firm grasp as Christchurch slowly spirals into full panic mode. Pick up a newspaper and the headlines are all about the Christchurch Carver, a serial killer who has been terrorising the city for the last few years. (Cemetery Lake, 2008:36)

The actions of the serial killer help the detective realise that Christchurch is a more complex place than commonly perceived. His perception of the city is highly negative, and he feels that nothing can be done to restore the postcard image which Christchurch was famous for. In this novel, Theodore comments that "Sometimes I think Christchurch is broken [...] and nobody is ever going to fix it" (Cemetery Lake 2008:53); this realisation shows that he is unable to restore law and order and to provide a reassuring ending typical of the classical detective story.

Interestingly, Tate's perception of the city evolves throughout the novel and becomes more and more similar to the serial killer's point of view. At the beginning of the story Tate tries to make a living as a private eye after losing his wife and daughter in a car accident. Suspected of killing the man whose careless driving ended the life of his daughter and reduced his wife to a vegetative state, he has resigned from the police force. The more he is involved in his investigation the more the 'broken' detective is able to see the other Christchurch that has always been there. Finally, in the last scene in the cemetery where the investigation started, he realises he has become a killer. Not only does he now know "exactly who I am" (Cemetery Lake, 2008:347), but he is also able to see his city in all its hidden facets.

In both these two authors' works, the serial killer seems to have the ability to see through the official image of the city and to detect its hidden face. In doing so, both serial killers appropriate a function 
which was typical of the flâneur of the nineteenth century, becoming a sort of new, terrifying postmodern flâneur. However, there is a difference between Lucarelli's Bologna and Cleave's Christchurch. Cleave's representation of his setting is confined to Christchurch city, traditionally divided into a centre and a periphery ${ }^{9}$. By contrast, Lucarelli also develops an important feature of postmodernity that is the idea of a sprawling area as a significant contemporary geographical space.

\section{Urban sprawl}

In Lucarelli's works, the mystery of Bologna is amplified by the fact that the city is much bigger than it seems. Not only does it expand vertically, down into its bowels, but also horizontally. In Almost Blue the writer takes up the notion of the capital of Emilia-Romagna as a huge metropolitan area that covers the old city, but also embraces a space that goes from Parma to Cattolica:

Questa città, le aveva detto Matera, non è come le altre città. [...] Lei dice piccola perché pensa a quello che sta dentro le mura, che è poco più di un paese, ma questa città lei non la conosce, ispettore, non la conosce proprio. Quella che lei chiama Bologna è una cosa grande che va da Parma fino a Cattolica, un pezzo di regione spiccicato lungo la via Emilia, dove davvero la gente vive a Modena, lavora a Bologna e la sera va a ballare a Rimini. Questa è una strana metropoli di duemila chilometri quadrati e due milioni di abitanti, che si allarga a macchia d'olio tra il mare e gli Appennini e non ha un vero centro ma una periferia diffusa che si chiama Ferrara, Imola, Ravenna o la Riviera. (Almost Blue, 1997:100)

9 New Zealand literature has been traditionally characterised by a rural setting. A dichotomy between life in the countryside and life in the city has emerged in the most recent production. Local literature reflects New Zealand's social geography, characterised by the presence of small and isolated villages and few cities. See Schafer (1998). 
The idea of a "periferia diffusa" applied to the Via Emilia is not an original concept of Lucarelli's, but a very old one which dates back to ancient Roman times. According to Franco Farinelli, the città-regione was the territorial model the Romans adopted for the area two thousand years ago, when all the cities lying along the old Via Emilia ${ }^{10}$ had the same administrative status. In other words, the area lacked a prominent centre that exercised a recognised executive power (Farinelli, 1984:7-30). In spite of the fact that the name 'Emilia' disappeared from official documents after the fall of the Roman Empire, the area kept its unity and identity thanks to the permanence of economic and road networks throughout the centuries (Savi, 1989:123). The establishment of the Emilia-Romagna region with its capital, Bologna, in the post-WWII period brought with it the amalgamation of two distinctive areas, Emilia and Romagna each with different cultural and historical identities (Papotti, 2001:12-16). Nonetheless, the unification created a new regional identity, through an aggregative process, the result of effective territorial management defined by scholars as the modello emiliano (Belpoliti, 1981).

However, the importance of the Via Emilia and its permanence in the region's culture is clearly demonstrated by an extensive literary production: several local writers have developed the image of a sprawling area in the surroundings of the Via Emilia ${ }^{11}$, an area that the poet Giulia Niccolai defines as "la Los Angeles dell'Italia" (Niccolai, 1986:137). This new trend of urban literature on the road, and specifically, on the Via Emilia, developed out of a more traditional one, which sees the Po River and its valley as its heart ${ }^{12}$. The passage

10 The Via Emilia was built under consul Marco Emilio Lepido between 189 and 187 B.C. in order to connect Rimini and Piacenza in a straight line. It still connects Rimini, Cesena, Forlì, Faenza, Imola, Bologna, Modena, Reggio, Parma, Fidenza, Fiorenzuola, and Piacenza.

11 See especially Pier Vittorio Tondelli (1985), Luciano Ligabue (1997), and Francesco Guccini (1989, 1993, 2004).

12 An older literary tradition linked to the Via Emilia has its roots in the peasant past of EmiliaRomagna. It starts with Giovannino Guareschi's (1908-1968) series with Peppone and don Camillo as its main characters, continuing on to Gianni Celati's travel literature. Eraldo 
from a rural setting to an urban one has seen the rise of some themes, such as alienation, loneliness and placelessness, which are typical of the postmodern urban experience (Nasi, 2001:3).

If in Almost Blue Bologna is still the centre of the investigation, the "periferia diffusa" is subsequently used as the main setting of $U n$ giorno dopo l'altro. This adventure develops in the broader EmiliaRomagna, including San Marino, with part of the investigation taking place in Lombardy and Lazio. Part of the story is also set in Bologna but throughout most of the adventure the readers follow Pit Bull in his murderous pilgrimage around Emilia-Romagna and beyond. More importantly, part of the action takes place in non-places, such as motorways, motorway restaurants and airports, as defined by Marc Augé (2008). In other words, some of the common features of urban sprawl permeate this novel. Pit Bull spends a lot of time in his car, driving along the motorway both to commit his crimes and to live his official life as a travelling salesman. The idea of the motorway as a non-place is illustrated in the following passage:

Quando stai guidando in autostrada, e ti chiamano al cellulare, e rispondi, e ti chiedono dove sei, e tu dici 'Sono a Pescara', non è vero. Non è lì Pescara, ci sono ancora due chilometri di rampe e di svincoli e altri nove di statale, e quando si è a undici chilometri da un posto, non si è lì, ma da un'altra parte. Se poi resti al telefono ancora una decina di minuti, e dall'altra parte ti chiedono 'Scusa, dove hai detto che sei?' non puoi più dire che sei a Pescara, ma a Roseto degli Abruzzi, se vai a nord, o a Chieti se vai a sud. E non sei neppure lì, a Roseto o a Chieti, ma da un'altra parte. Sei in autostrada. (Un giorno dopo l'altro, 2000:173)

Baldini's works are a notable example of mystery stories set in foggy landscapes and silent swamps. For a more detailed view of Emilia Romagna writers who set their stories along the Via Emilia or the Po River, see Bertoni and Anselmi (1997), Nasi (2001), and Papotti (2007) 
The narrator implies that on the motorway, one is not at a specific geographical point, but in an indistinct space called motorway, a typical non-place. For Vittorio, aka Pit Bull, when you are on a motorway, you can only look forward. Therefore, the landscape that runs along the sides always looks the same.

In autostrada, pensava Vittorio, per chi guida tutto è davanti. Ai lati non si può guardare, non si può girare la testa e osservare, fissare, scrutare, tutto quello che scorre lungo i finestrini viene percepito con la coda dell'occhio ed è tutto uguale. Guardrail di cemento grigio, lungo, piatto e compatto come un muro. Strisce di metallo concavo segnate ogni tanto dal foruncolo rossastro di un catarifrangente. Siepi squadrate di rami verdi, selvagge di fiori malati. Barriere di plexiglas. (Un giorno dopo l'altro, 2000:109)

In such a non-place, blurred objects and indistinct scenery follow one another, contributing to an increased feeling of alienation: the motorway ceases to be a geographical and physical feature and becomes a geometrical and abstract idea:

Autostrada, una geografia che non segue il paesaggio ma lo taglia e che può essere disegnata come un albero da bambini: con due righe parallele e righine singole che se ne distaccano, tutte uguali a parte l'indicazione sul cartello dell'uscita. (Un giorno dopo l'altro, 2000:177)

This space of alienation, isolation and placelesssness is the ideal environment for a serial or a professional killer, who can take advantage of its anonymity to commit his crimes. The sprawling area, more commonly associated with American cities and the figure of the serial killer is woven into Lucarelli's novels. The concept of urban sprawl is introduced by policeman Matera in Almost Blue. However, interestingly, in Un giorno dopo l'altro it is Pit Bull, the serial killer (who lives, drives, eats and kills in it) who is able to fully understand 
the inner essence of the place where he moves. In other words, his position of alienation gives him a better perspective into the alienated nature of urban sprawl, just as Cleave's Joe, with his double personality, is able to detect Christchurch schizophrenic nature.

\section{Conclusion}

In conclusion, both authors give an account of a postmodern city, whose mysteriousness is magnified by the juxtaposition of the different presentations of a fragmented reality through various voices. However, in both cases, it is the postmodern figure of the alienated, yet acutely sensitive serial killer who embodies its fragmented and elusive identity. Paraphrasing Philip Howell's words (1998), walking and driving the city and the region in search for their victims, the serial killer conveys a form of knowledge of the city that is linked to everyday spatial practices, resulting in a genuinely urban epistemology. Overlapping, and in some cases, substituting the detective in his epistemological function, the serial killer gives an interpretation of the city, a "word-city" and does not exhaust the empirical and physical urban space. Rather, he contributes to delivering what Highmore (2005) calls a "lived metaphoricity" (5) of the urban space, characterised by loneliness, selfishness, violence and alienation. In other words, through the vital figure of the serial killer, Lucarelli's and Cleave's crime fiction reflects and reflects upon the postmodern city, defying its illegibility.

\section{References}

$\begin{array}{lll}\text { Augé, M. } & 2008 & \begin{array}{l}\text { Non-places: Introduction to an } \\ \text { Anthropology of Supermodernity. London } \\ \text { and New York: Verso. }\end{array} \\ \text { Belpoliti, M. } & 1981 \quad \begin{array}{l}\text { Effetto Emilia. Bologna: Edizioni Officina } \\ \text { Immagine. }\end{array}\end{array}$




\begin{tabular}{|c|c|c|}
\hline Benjamin, W. & $\begin{array}{c}2003 \\
{[1938]}\end{array}$ & $\begin{array}{l}\text { The Paris of the Second Empire in } \\
\text { Baudelaire. In Selected Writings. } 4 \text { vols. } \\
\text { Vol 4, 3-94. Bullock, Marcus and Michael } \\
\text { W. Jennings, eds. Cambridge, MA: } \\
\text { Belknap Press of Harvard University Press. }\end{array}$ \\
\hline $\begin{array}{l}\text { Bertoni, A. \& } \\
\text { Anselmi G.M. }\end{array}$ & 1997 & $\begin{array}{l}\text { Una geografia letteraria tra Emilia e } \\
\text { Romagna. Bologna: CLUEB. }\end{array}$ \\
\hline Cleave, $\mathrm{P}$. & $\begin{array}{l}2006 \\
2007\end{array}$ & $\begin{array}{l}\text { The Cleaner. Auckland: Random House. } \\
\text { The Killing Hour. Auckland: Random } \\
\text { House. }\end{array}$ \\
\hline & $\begin{array}{l}2008 \\
2010\end{array}$ & $\begin{array}{l}\text { Cemetery Lake. Auckland: Random House. } \\
\text { Blood Men. Christchurch: Atria, } 2010 .\end{array}$ \\
\hline de Certeau, M. & 1984 & $\begin{array}{l}\text { The Practice of Everyday Life. Berkeley, } \\
\text { Los Angeles and London: University of } \\
\text { California Press. }\end{array}$ \\
\hline Farinelli F. & 1984 & $\begin{array}{l}\text { I lineamenti geografici della conurbazione } \\
\text { lineare emiliano-romagnola. Bologna: } \\
\text { Istituto di Geografia dell'Università di } \\
\text { Bologna. }\end{array}$ \\
\hline Geherin, D. & 2008 & $\begin{array}{l}\text { Scene of the Crime. The Importance of } \\
\text { Place in Crime and Mystery Fiction. } \\
\text { Jefferson and London: McFarland \& } \\
\text { Company Publishers. }\end{array}$ \\
\hline Guccini, F. & 2004 & Cittanova Blues. Milan: Feltrinelli. \\
\hline & 1989 & Croniche epafàniche. Milan: Feltrinelli. \\
\hline & 1993 & Vacca d'un cane. Milan: Feltrinelli. \\
\hline Halbertstam, J. & 1991 & $\begin{array}{l}\text { Skinflick: 'Posthuman Genre' in Jonatham } \\
\text { Demme's The Silence of the Lambs. } \\
\text { Camera Obscura 27: } 37-53 \text {. }\end{array}$ \\
\hline Hausladen, G. & 2000 & $\begin{array}{l}\text { Places for Dead Bodies. Austin: University } \\
\text { of Texas Press. }\end{array}$ \\
\hline
\end{tabular}




\begin{tabular}{|c|c|c|}
\hline Highmore, B. & 2005 & $\begin{array}{l}\text { Cityscapes. Cultural Reading in the } \\
\text { Material and Symbolic City. Houndsmills, } \\
\text { Basingstoke and New York: Palgrave } \\
\text { MacMillan. }\end{array}$ \\
\hline Howell, P. & 1998 & $\begin{array}{l}\text { Crime and the City Solution: Crime } \\
\text { Fiction, Urban Knowledge, and Radical } \\
\text { Geography. Antipode } 30 \text { (4): } 357-78 \text {. }\end{array}$ \\
\hline Lehan, R. & 1998 & $\begin{array}{l}\text { The City in Literature. An Intellectual and } \\
\text { Cultural History. Berkeley, Los Angeles } \\
\text { and London: University of California } \\
\text { Press. }\end{array}$ \\
\hline Ligabue, L. & 1997 & $\begin{array}{l}\text { Fuori e dentro il borgo. Milan: Baldini e } \\
\text { Castoldi. }\end{array}$ \\
\hline Lucarelli, C. & 1997 & Almost Blue. Turin: Einaudi. \\
\hline & 2001 & $\begin{array}{l}\text { Almost Blue. San Francisco: City Lights } \\
\text { Publishers. }\end{array}$ \\
\hline & 2004 & Day after Day. London: Harvill Press. \\
\hline & 1994 & $\begin{array}{l}\text { Lupo Mannaro. Bologna: Metrolibri and } \\
\text { Granata Press. }\end{array}$ \\
\hline & 1992 & $\begin{array}{l}\text { Nikita. In Moscati, M. (ed) Il delitti del } \\
\text { Gruppo 13. Bologna: Metrolibri and } \\
\text { Granata Press. }\end{array}$ \\
\hline & 2000 & Un giorno dopo l'altro. Turin: Einaudi. \\
\hline Macfie, R. & & $\begin{array}{l}\text { What lies Beneath. NZ Listener } 222 \\
(3642) \text {. }\end{array}$ \\
\hline Mondello, E. & 2005 & $\begin{array}{l}\text { Il Neonoir. Autori, editori, temi di un } \\
\text { genere metropolitano. Roma Noir 2005. In: } \\
\text { Mondello, E. (ed) Tendenze di un nuovo } \\
\text { genere metropolitano, 15-42. Rome: } \\
\text { Robin:15-42. }\end{array}$ \\
\hline
\end{tabular}




\begin{tabular}{|c|c|c|}
\hline Most, G.W. & 2006 & $\begin{array}{l}\text { Urban Blues: Detective Fiction and the } \\
\text { Metropolitan Sublime. The Yale Review } 94 \\
\text { (1):56-72. }\end{array}$ \\
\hline \multirow[t]{2}{*}{ Nasi, F. (ed) } & 2001 & $\begin{array}{l}\text { Intorno alla via Emilia. Boca Raton: } \\
\text { Bordighera Press. }\end{array}$ \\
\hline & & $\begin{array}{l}\text { Intorno alla via Emilia. Note introduttive } \\
\text { per orientarsi. In: Nasi, F. (ed) Intorno alla } \\
\text { via Emilia. Boca Raton: Bordighera } \\
\text { Press:1-9. }\end{array}$ \\
\hline Niccolai, G. & 1986 & $\begin{array}{l}\text { La via Emilia. In: Bizzarri, G. (ed) } \\
\text { Esplorazioni sulla via Emilia. Scritture nel } \\
\text { paesaggio. Milan: Feltrinelli:123-145. }\end{array}$ \\
\hline \multirow[t]{2}{*}{ Papotti, D. } & 2001 & $\begin{array}{l}\text { Emilia-Romagna: variazioni geografiche } \\
\text { su un'identità culturale regionale. In: Nasi, } \\
\text { F. (ed) Intorno alla via Emilia. Boca } \\
\text { Raton: Bordighera Press:11-32. }\end{array}$ \\
\hline & 2007 & $\begin{array}{l}\text { Il fiume Po e le sue letterature. In: Pieri, P. } \\
\text { \& Crepella, C. (eds) Atlante dei movimenti } \\
\text { culturali dell'Emilia-Romagna. Bologna: } \\
\text { CLUEB:11-36. }\end{array}$ \\
\hline Peach, L. & 2006 & $\begin{array}{l}\text { Masquerade, Crime and Fiction. Criminal } \\
\text { Deceptions. Houndsmills, Basingstoke: } \\
\text { Palgrave McMillan. }\end{array}$ \\
\hline Pike, B. & 1981 & $\begin{array}{l}\text { The Image of the City in Modern } \\
\text { Literature. Princeton: Princeton University } \\
\text { Press. }\end{array}$ \\
\hline Plain, G. & 2001 & $\begin{array}{l}\text { Twentieth-Century Crime Fiction. Gender, } \\
\text { Sexuality and the Body. Edimburgh: } \\
\text { Edimburgh University Press. }\end{array}$ \\
\hline $\begin{array}{r}\text { Prendergast, } \\
\text { C. }\end{array}$ & 1992 & $\begin{array}{l}\text { Paris and the Nineteenth Century. Oxford: } \\
\text { Blackwell. }\end{array}$ \\
\hline
\end{tabular}




$\begin{array}{lcl}\text { Righini, M. } & 2003 & \begin{array}{l}\text { Come si costruisce un luogo letterario: } \\ \text { Bologna nera. Delitti di carta 4:79-100. }\end{array} \\ \text { Roth, M. } & 1995 & \begin{array}{l}\text { Foul and Fair Play: Reading Genre in } \\ \text { Classic Detective Fiction. Athens, GA: } \\ \text { University of Georgia. }\end{array} \\ \text { Savi, F. } & 1989 & \begin{array}{l}\text { Strada e territorio. In Aemilia. Una via, una } \\ \text { regione. Parma: Rotary Club Parma Est. }\end{array} \\ \text { Schafer, W.J. } & 1998 & \begin{array}{l}\text { Mapping the Godzone: a Primer on New } \\ \text { Zealand Literature and Culture. Honolulu: } \\ \text { University of Hawai'I Press. }\end{array}\end{array}$

Seltzer, M. 1993

Sharpe, W. \&

Wallock, L.

Soja, E.

Somigli, L.

Stevens, J.

Tondelli, P.V.

1987
Serial Killers (I). Differences: A Journal of Feminist Cultural Studies 5 (1):92-128.

From 'Great Town' to 'Nonplace Urban Realm': Reading the Modern City. In Sharpe, W. \& Wallock, L. (eds) Visions of the Modern City: Essays in History, Art and Literature. Baltimore and London: Johns Hopkins University Press:1-50.

2000 Postmetropolis: Critical Studies of Cities and Regions. Oxford: Blackwell.

2010 The Mysteries of Bologna: On Some Trends of the Contemporary Giallo. In Giuliana Pieri (ed). Italian Crime Fiction. Cardiff: University of Wales Press.

Forthcoming.

1966 The New Zealand Novel (1860-1965). Auckland: Reed Publishing, 1966.

1985 Rimini. Milan: Bompiani. 
Tygstrup, F.

The Literary City: Between System and Sensation. In: Tinkler-Villani, V. (ed) Babylon or New Jerusalem? Perceptions of the City in Literature. Amsterdam and New York: Rodopi: 225-38. 